\title{
Goffman's Backstage Revisited: Conceptual Relevance in Contemporary Social Interactions
}

\author{
Sandro Serpa ${ }^{1} \&$ Carlos Miguel Ferreira ${ }^{2}$ \\ ${ }^{1}$ University of the Azores, Faculty of Social and Human Sciences, Department of Sociology; Interdisciplinary Centre of \\ Social Sciences -CICS.UAc/CICS.NOVA.UAc, and Interdisciplinary Centre for Childhood and Adolescence -NICA - \\ UAc, Ponta Delgada, Azores, Portugal \\ ${ }^{2}$ Interdisciplinary Centre of Social Sciences-CICS.NOVA, Polytechnic Institute of Castelo Branco, Estoril Higher \\ Institute for Tourism and Hotel Studies, 1069-061 Lisbon, Portugal \\ Correspondence: Sandro Serpa, University of the Azores, Faculty of Social and Human Sciences, Department of \\ Sociology, 9501-801 Ponta Delgada, Azores, Portugal. Email: sandro.nf.serpa@uac.pt
}

Received: July 24, 2018

doi:10.11114/ijsss.v6i10.3659
Accepted: September 19, 2018

Available online: September 26, 2018

\begin{abstract}
Goffman's analytical proposal for the interpretation of situations of interaction was, according to the author himself, expressly formulated for face-to-face situations with the actors physically present. This conceptual paper aims to analyse some highlights specifically about backstage - its conceptual meaning and its potential heuristic relevance for the interpretation of social interactions in the contemporary world. For this purpose, a documentary selection geared by the concept of backstage was carried out, which allows considering that the sociological understanding of the interactions that take place in an online context could be deepened with an enhancement of Goffman's theory considering that there is a tendency to a greater plasticity in the presentation of the self in this type of interactions with a greater identity flow.
\end{abstract}

Keywords: backstage, front stage, online interaction, digital, self-presentation, identity, Goffman

\section{Introduction}

Erving Goffman (1922-1982) has been repeatedly categorised as a sociologist of interaction. Interaction relationships are relationships between people, organised in particular by the use of shared resources and communication rules. It is important to distinguish relationships between people and relationships between relationships. Relationships between groups are relationships between sets of people, and talking about sets of people is talking about relationships between people. That is, relationships between groups are relationships between relationships between people, inasmuch that each group is already a particular set of relationships between people (Pires, 2012, p. 40).

The author's analytical proposal was not limited to the scope of interaction (Galindo, 2015); he sought to demonstrate that the organisation of interaction enabled and translated the connection between the micro and macro levels of the sociological analysis (Plummer, 2000), although he noted:

My concern over the years has been to promote acceptance of this face-to-face domain as an analytically viable one - a domain which might be titled, for want of any happy name, the interaction order - a domain whose preferred method of study is microanalysis. My colleagues have not been overwhelmed by the merits of the case (Goffman, 1983, p. 2, cit. in Walsh \& Baker, 2017, p. 1199).

Goffman's analytical proposal for the interpretation of situations of interaction was, according to the author himself, expressly formulated for face-to-face situations with the actors physically present. This conceptual paper aims to analyze some highlights specifically about its concept of backstage - its meaning and its potential heuristic relevance for the sociological interpretation of social interactions in the contemporary world. To that end, the concept of backstage in the sociological analysis will be addressed, focusing in particular on the following topics: social order and autonomy, face-to-face interaction, and, finally, social interactions that take place in an online context. 


\section{Backstage in the Analysis of Social Interactions}

\subsection{Social Order and Autonomy}

Society exists to the extent that there is a minimum predictability of expectations among individuals that enables organising a social order. Social order may be defined in factual terms as the standardisation that emerges from the relational processes of interaction, grouping and systemic interdependence (Pires, 2012). Social order is embodied in patterns of social relationships. These patterns are observable in multiple domains and at different scales, in the similarities of individual behaviours, in the regularities of encounters between human agents, in the establishment of groups and organisations, in the functioning of institutions and in the distribution of social resources (Pires, 2012).

According to Javeau (1998), "social order rules in two ways: it sets the framework for my habitual behaviours and imposes on these behaviours that they take place in a certain way" (p. 176), which results in dynamic stability through a process of legitimation attained, to a great extent, through the processes of socialisation.

Social institutions are involved in these processes of socialisation. According to Giddens (1997), these processes of socialisation consist of

Basic modes of social activity followed by the majority of members of a given society. Institutions entail norms and values to which most individuals submit and that all institutionalised modes of behaviour are safeguarded by strong sanctions. Institutions are the pillar of a society, inasmuch that they typify relatively constant modes of behaviour that endure through times (p. 869).

That is to say, through rules of behaviour and shared ideals considered as the most appropriate in a given social situation, which reward or sanction, as they are complied or respected, or they are not respected. The author concludes that "Social institutions are the 'cement' of social life. They provide the basic living conditions that human beings create in their interaction and through which continuity is achieved over the generations" (Giddens, 1997, p. 459).

However, through formal and/or informal social (self)control, zones of indeterminacy always persist (Goffman, 2007, 1999), in addition to the fact that permanent self-control is not possible (Javeau, 1998). As an example, Goffman (2007) presents the extreme case of total or totalitarian institution as "a social hybrid, partly residential community, partly formal organisation" (p. 22), defined as "a place of residence and work where a large number of individuals with a similar situation, separated from the wider society for a considerable period of time, live a closed and formally administered life" (p. 11). Among these, the author mentions, as examples, asylums, prisons, convents, concentration camps and boarding schools, and "Even in extreme situations, organisational actors discover or create spaces of (some) autonomy, in which they exert their (even if highly regulated) freedom beyond the structure of the organisation, which is acknowledged by Goffman himself" (Serpa, 2014, p. 3).

According to Goffman (2007), the actor may attempt, through the established social order, to seek individuality in the performance of his/her role during social interaction:

Without something which we belong to, we do not have a stable self; nevertheless, total commitment and attachment to any social unit presuppose a kind of absence of the self. Our feeling of being a person may stem from the fact that we are placed in a larger social unit; our feeling of having a self can emerge through the small forms of resistance to that attraction. Our status rests on the solid constructions of the world, whereas our sense of personal identity often lies in its cracks (p. 259).

\subsection{Face-to-face Interactions}

Goffman (1993) uses theatre metaphors in the analysis of face-to-face interactions, considering this interaction as "the reciprocal influence of individuals on each others' actions in a situation of immediate physical presence" (p. 26), as if fulfilling a theatrical performance. According to Goffman (1993), the individual, as an actor, in this interaction, tends to seek to fulfill the shared expectations through the information he/she conveys about him/herself, whether it is intentional or not, more or less controllable, has a verbal nature or not, giving a positive impression about him/herself: "The information about the individual helps to define the situation, allowing others to know beforehand what the individual expects of them and what they can expect from the individual" (p. 11). Extreme cases of noncompliance with these expectations may ultimately lead to stigma: "the situation of the individual who is incapacitated for full social acceptance" (Goffman, 1988, p. 7), affected in his/her identity.

For Goffman (1993), social performance takes place on the front stage,

[...] that part of the individual's performance that functions regularly in a generic and fixed way in order to define the situation for those who observe the performance $[\ldots]$ is the expressive equipment of a standardised type, used intentionally or unconsciously by the individual during his/her performance" (p. 34).

Concurrently, there is the backstage, "a back area or backstage may be defined as a place, connected with a given 
performance, where the impressions aimed at by this performance are consciously contradicted in a natural manner" ( $\mathrm{p}$. 136), in which "the actor can relax, put aside his/her disguise, interrupt the performance and abandon the character that he/she plays in the respective frame" (p. 135). This is a restricted area, not in the public domain and without access to the viewers (Mueller, 2018; Bute, 2016).

Below there are some illustrations of the relevance of using the concept of backstage in studies that address various social situations, respectively, teamwork in sport, women's football, children of parents with alcohol problems, hospice workers, professional teamwork in preschool and finally corporate interests:

Thus it is vital for team solidarity to keep some serious problems and conflict backstage. Also, many key elements, such as friendship, trust and strong social bonds, that strengthen group solidarity are developed backstage. [...] Finally, knowing that everybody honors the code of keeping up good appearances frontstage and leaving the problems backstage adds to the the team cohesion. In other words, secrecy plays an important part in honoring and maintaining the team ethos (Halldorsson, Thorlindsson, \& Katovich, 2017, p. 1293);

[...] we stress the presence of the concern in moving and having a neat hair, flawless uniform and boots, and nice looking nails - tricks that aim to relate the identity of the woman soccer player to the image of the woman present in different "locus" of society, hiding possible stigmas fostered by the modality [...] there is rather a careful preparation invested in the backstage region (in the locker rooms) to generate a good and convincing performance in the front stage region (Salvini, Souza, \& Marchi Júnior, 2015, pp. 565 and 566);

The social interaction in the family was disrupted during childhood because of the parent's drinking problems. An everyday drama characterized by tension and threats, blame and manipulation was the backstage of their everyday life. Dealing with the drama, the children experienced limited parental support. Some children felt betrayed by the other parent who might trivialize the problems and excuse the drinking parent. Family activities and routines were disturbed, and uncertainty and insecurity was created. The children struggled to restore social order within the family and to act as normally as possible outside the family (Werner \& Malterud, 2016, p. 1);

Front stage behaviors emphasize compassion, while backstage behaviors include dark humor, strategizing, and detachment (Cain, 2012, p. 668);

Two activities appeared to be nested: accounting for the situation backstage by reviewing the "true story" and accounting for why some backstage accounts cannot be presented front stage. Two kinds of professionalism appeared to be present: practical knowledge about working with toddlers and practical knowledge about how to deal with complaining clients (Aili \& Nilsson, 2018, p. 228);

[...] we argue that corporate activities can be divided into frontstage and backstage performance. Frontstage activities are externally oriented activities aiming to manage relationships with stakeholders in order to repair or maintain legitimacy, while backstage activities are internally oriented management activities aiming to foster corporate interests away from those same stakeholders' scrutiny. In the context of our study, we consider voluntary sustainability reporting in stand-alone reports as the frontstage corporate activities, whereas corporate political strategies such as political campaign contributions are envisioned as backstage corporate activities (Cho, Laine, Roberts, \& Rodrigue, 2016, p. 5).

Backstage areas are, hence, like the backstage of a theatre outside the stage. Backstage allows actors to prepare their performance on stage by preparing their more formal performance to perform a role (Bute, 2016; Cain, 2012; Chen \& Wang, 2018; Cho et al., 2016; Giddens, 1997; Goffman, 1993; Leigh, 2017). According to Cain (2012), "The two regions have a symbiotic relationship in that activities in the backstage allow workers to maintain appropriate behaviors during the front stage, while front stage activities provide fodder for discussions and activities in the back region" (p. 669).

But what about situations of interaction that do not take place face-to-face? What is the relevance of backstage? Goffman deals only with face-to-face situations with the persons being physically present: "on every occasion when two or more persons are in one another's immediate physical presence, a complex set of norms will regulate the commingling" (Goffman, 1986, p. 495). Is this backstage idea relevant and with heuristic ability if applied in the interactions that are established through digital means, as it happens with the possibility of online social interactions that occur a lot in the contemporary context (Vigmo \& Lantz-Andersson, 2014)?

\subsection{Online Social Interactions}

However, the question remains about what is the analytical ability to approach backstage in an increasingly technological and online context, in which the demarcation between backstage and front stage is more tenuous (Thornborrow \& Haarman, 2012; Vigmo \& Lantz-Andersson, 2014), bringing some of the private domain to the public 
domain "in the context that cultures of communication on social media tend to embody freedom and openness of expression" (Bullock, 2018, p. 356).

Technology itself influences backstage and interaction processes (Andersson, 2017; Richey, Gonibeed, \& Ravishankar, 2017; Walsh \& Baker, 2017). As an illustration of the influence of the context in interaction, Andersson (2017) considers in her study that students adjust their performance in the search for information according to their assessment of the school's general context, but also of the situation in question, case by case, equating, in a way, frontstage with legitimacy and backstage with non-legitimacy:

$[\ldots]$ the use of technology opened up for a new backstage within the classroom - for teachers as well as pupils. For example, during English class the teacher used information resources but did not reveal them to the pupils [...] However, the teacher uses the word dictionary without denoting any specific dictionary, therefore giving limited information to the pupils. The searching in the dictionary remains backstage even though it happens in the class room. The pupils only see and hear what the teacher wants them to (Andersson, 2017).

The online dimension is taking on growing importance in learning. Gilmore (2014) puts forward a subdivision within the very concept of backstage in online education:

1. Front stage online: The space where an online student gives a performance. This space can be "seen" by the university; for example, the online discussion board and student activity logs.

2. Backstage online: A space where an online student prepares for a performance using the Internet but cannot be seen by the university; for example, websites, Facebook, and email.

3. Backstage offline: A space where an online student prepares for a performance without an Internet connection; for example, in a Word document, in face-to-face conversations, and in self-talk (p. 187).

Hence, in the contemporary world, the actor's performance can take place in a virtual context, for example through social networks such as Facebook, Tweeter or Instagram, despite the differences between them (Brownlie \& Shaw, 2018; Chen, 2018, Greer \& Ferguson, 2017; Leaver \& Highfield, 2018; McMahon, McGannon, \& Zehntner, 2017; Vigmo \& Lantz-Andersson, 2014) and digital language itself can be embodied in different forms of communication that takes place in face-to-face interaction, using, for instance, emoticons ("facial expressions with punctuation marks, numbers and letters"), emojis ("ideograms"), and emotes ("text entries that indicate an action taking place") (Lyons, 2018, p. 19).

The students' posting becomes an example of how they resist any definition of the situation, making use of their digital vernacular utilizing language in the wild, that is bantering by playing ironically with their own performance, laughing, posing together for a selfie, one in which is pouting his lips and the other is trying to look sexy in a self-mocking activity. . [...] The classroom, thus, can be seen as both back and front stage, thereby blurring spaces (Vigmo \& Lantz-Andersson, 2014, p. 888)

In this performance in social networks and as stated by Richey, Gonibeed, and Ravishankar (2018),

Many of the participants recognised that their prolonged reflection was contrary to the commonly understood design of sites like Twitter. They understood that many of these social media sites were intended to involve responsive and immediate posting. Yet they found that giving themselves space to prepare became vital to retaining a sense of control over their social media images. They asked themselves many questions about the content of their posts, examining each from different moral and social perspectives (p. 432).

Several studies conclude that the difference between front image and back image, between public and private, in online and offline context is much more diluted than in the examples provided by Goffman (Chen, 2018; Lyons, 2018; Richey et al., 2018; Vigmo \& Lantz-Andersson, 2014; Walsh \& Baker, 2017; Wilkinson, 2017) and, thus, it is more tenuous to find "a clear contrast between two different social worlds, described by Goffman as backstage and frontstage. By situating a team in different social contexts provides us with the opportunity to analyze teams on two distinct levels" (Halldorsson et al., 2017, p. 1293). For example, with the proliferation of selfies,

[...] the selfie is subject to the increasing ambiguity that is creeping into the public-private division; the practice of taking selfies is emblematic of the blurring of the boundary between public and private social life. The proliferation of selfie as a form of visual expression is connected to the increasing desire to communicate an ideal image of the self. The desire to stay connected regardless of one's location renders the division between public and private less significant (Walsh \& Baker, 2017, p. 1198).

In short, the interaction that takes place in an online context may be considered as follows: "they function as triggers of multimodal associations activated by recipients' prior offline experience and familiarity with modality conventions, based on prior online experiences" (Lyons, 2018, p. 20), where "our participants coped by creating a third cognitive space that was neither a formal front stage nor a completely relaxed backstage. The participants imagined the potential 
audience for their posts or forced themselves to pause and think two or three times about the content they were about to share" (Richey et al., 2018, p. 434).

According to Qi, Monod, Fang, and Deng (2018), Goffman's proposal has limitations in the understanding of personal life, as well as of the use of social media (having a greater potential in the analysis of situations of performance of a professional role). From the features that distinguish Goffman's proposal from the Information Systems review by Qi et al. (2018, p. 97), we highlight, in short, the features that value aspects such as the creativity of the actor's autonomy on social media "perform imaginative performances on social media", "control my performance", "display imagined affordances", "choose the features of myself I want to share with others".

Regarding the limitations of the implementation of Goffman's proposal, it is necessary "an approach that connects systematic features of the structural and relational position of persons with the concrete characteristics of situations in which interaction occurs" (Lizardo \& Collett, 2013, p. 353), as well as "a world of multiple values results in mixed-motive games and decision dilemmas for participants, for instance between instrumental gain, on the one hand, and realization of counter-norm, on the other hand, or conflict between different norms, or between divergent instrumentalities" (Burns, Roszkowska, Machado Des Johansson, \& Corte, 2018, p. 9), which adds further complexity due to "the digital turn within sociology foregrounds the complexity of how we can read emotion in and through text" (Brownlie \& Shaw, 2018, p. 2).

In sum, and as stated by Richey et al. (2018),

Rather than discarding the performance metaphor, we propose that the inclusion of additional theatrical forms to the theoretical framework can refresh and supplement our understanding of social media's role in self presentations.

Based on our data we propose an alternative view of social media presentations as post-modern performances, akin to forms of theatre that blur the boundaries between the front and backstage to remind the audience that a performance is merely a representation of reality, not reality itself. Similarly, our participants brought content that would typically be consigned to life outside of their organisations into their social media performances. By including their personal interests and experiences in their professional performances they reminded their colleagues that there was much more to them than could be seen at work [...]. Social media enabled our participants to enact similar styles of performance, allowing them to drop their formal performances temporarily, although like a post-modern troupe, they were still performing. This was a different style of performance, still intended for a formal audience, but designed to guide them in drawing new conclusions by revealing information normally related to the backstage. These glimpses fed into front stage selfpresentations although they were not traditionally associated with that realm (p. 434).

\section{Conclusion}

According to Goffman, "the crucial role of performance based on idealizations" (Mueller, 2018, p. 26). However, "for Goffman the actor is not only mind, but body; he/she is not only normative, but strategic, and his/her rationality does not only operate according to formal principles, but it is an eminently practical instance" (Galindo, 2015, p. 32). Thus, "Based on Goffman, we have argued that reality is not only socially constructed but is constructed in and through performances" (Muller, 2018, p. 27).

Notwithstanding the potential of Goffman's proposal for the analysis of an increasingly digital world (Vigmo \& Lantz-Andersson, 2014; Leigh, 2017; Bullock, 2018; Portillo, Rudes, Viglione, \& Nelson, 2013; Cho et al., 2016), there seems to be a greater plasticity in the presentation of the self in an online context, in a more fluid identity (Hanusch, 2017; Leaver \& Highfield, 2018; Lyons, 2018), in which the professional, social and personal dimensions can be combined (Hanusch, 2017).

The sociological understanding of the interactions that take place in an online context could be deepened with an enhancement of Goffman's theory (Richey et al., 2018). However, there is always a backstage in the Goffmian sense, in which "You do not want to know how the sausage is made" (Bute, 2016, p. 500).

\section{Acknowledgments}

University of Azores, Interdisciplinary Centre of Social Sciences - CICS.UAc/CICS.NOVA.UAc, UID/SOC/04647/2013, with the financial support of FCT/MEC through national funds and when applicable co-financed by FEDER under the PT2020 Partnership Agreement.

The authors acknowledge the comments and suggestion by two anonymous reviewers. 


\section{References}

Aili, C., \& Nilsson, L.-E. (2018). Backstage accounting in preschool: Analysing dealing with complaints as "rehearsing away" professional knowledge. Ethnography and Education, 13(2), 218-234. https://doi.org/10.1080/17457823.2017.1318080

Andersson, C. (2017). The front and backstage: Pupils' information activities in secondary school. Information Research, 22(1), CoLIS paper 1604. http://InformationR.net/ir/22-1/colis/colis1604.html (Archived by WebCite® at http://www.webcitation.org/6oUBxdxBL). June 1, 2018.

Brownlie, J., \& Shaw, F. (2018). Empathy rituals: Small conversations about emotional distress on Twitter. Sociology, Onine First, 1-19. https://doi.org/10.1177/0038038518767075

Bullock, K. (2018). (Re)presenting “order" online: The construction of police presentational strategies on social media. Policing and Society, 28(3), 345-359. https://doi.org/10.1080/10439463.2016.1177529

Burns, T., Roszkowska, E., Machado Des Johansson, N., \& Corte, U. (2018). Paradigm shift in Game Theory: Sociological re-conceptualization of human agency, social structure, and agents' cognitive-normative frameworks and action determination modalities. Social Sciences, 7(3), 1-40. https://doi.org/10.3390/socsci7030040

Bute, M. (2016). A backstage sociologist: Autoethnography and a populist vision. The American Sociologist, 47(4), 499-515. https://doi.org/10.1007/s12108-016-9307-z

Cain, C. L. (2012). Integrating dark humor and compassion. Journal of Contemporary Ethnography, 41(6), 668-694. https://doi.org/10.1177/0891241612458122

Chen, H. (2018). College-aged young consumers' perceptions of social media marketing: The story of Instagram. Journal of Current Issues \& Research in Advertising, 39(1), 22-36. https://doi.org/10.1080/10641734.2017.1372321

Chen, Y. M., \& Wang, M. Y. (2018). Applying dramaturgy theory in computer maintenance services. Services Marketing Quarterly, 39(1), 35-48. https://doi.org/10.1080/15332969.2017.1398027

Cho, C. H., Laine, M., Roberts, R. W., \& Rodrigue, M. (2016). The frontstage and backstage of corporate sustainability reporting: Evidence from the Arctic National Wildlife Refuge Bill. Journal of Business Ethics, 1-22. https://doi.org/10.1007/s10551-016-3375-4

Galindo, J. (2015). Erving Goffman y el orden de la interacción [Erving Goffman and the interaction order]. Acta Sociológica, 66, 11-34. https://doi.org/10.1016/j.acso.2014.11.002

Giddens, A. (1997). Sociologia [Sociology]. Lisboa: Fundação Calouste Gulbenkian.

Gilmore, D. M. (2014). Goffman's front stage and backstage behaviors in online education. Journal of Learning Analytics, 1(3), 187-190. https://doi.org/10.18608/jla.2014.13.19

Goffman, E. (1986). Frame analysis. An essay on the organization of experience. Boston: Northeastern University Press.

Goffman, E. (1988). Estigma. Notas sobre a manipulação da identidade deteriorada [Stigma. Notes on manipulating the deteriorated identity]. Rio de Janeiro: Editora Guanabara.

Goffman, E. (1993). A apresentação do eu na vida de todos os dias [The presentation of self in everyday life]. Lisboa: Relógio d'Água.

Goffman, E. (1999). Os momentos e os seus homens [The moments and their men]. Lisboa: Relógio D’Água.

Goffman, E. (2007). Manicômios, prisões e conventos [Asylums, prisons and convents]. São Paulo: Editora Perspectiva.

Greer, C. F., \& Ferguson, D. A. (2017). The local TV station as an organizational self: Promoting corporate image via Instagram. International Journal on Media Management, 19(4), $282-297$. https://doi.org/10.1080/14241277.2017.1383255

Halldorsson, V., Thorlindsson, T., \& Katovich, M. A. (2017). Teamwork in sport: A sociological analysis. Sport in Society, 20(9), 1281-1296. https://doi.org/10.1080/17430437.2017.1284798

Hanusch, F. (2017). Political journalists' corporate and personal identities on Twitter profile pages: A comparative analysis in four Westminster democracies. New Media \& Society, 20(4), 1488-1505. https://doi.org/10.1177/1461444817698479

Javeau, C. (1998). Lições de Sociologia [Sociology lessons]. Oeiras: Celta Editora.

Leaver, T., \& Highfield, T. (2018). Visualising the ends of identity: Pre-birth and post-death on Instagram. Information, Communication \& Society, 21(1), 30-45. https://doi.org/10.1080/1369118x.2016.1259343 
Leigh, J. (2017). Recalcitrance, compliance and the presentation of self: Exploring the concept of organisational misbehaviour in an English local authority child protection service. Children and Youth Services Review, 79, 612619. https://doi.org/10.1016/j.childyouth.2017.07.016

Lizardo, O., \& Collett, J. L. (2013). Embarrassment and social organization: A multiple identities model. Social Forces, 92(1), 353-375. https://doi.org/10.1093/sf/sot078

Lyons, A. (2018). Multimodal expression in written digital discourse: The case of kineticons. Journal of Pragmatics, 131, 18-29. https://doi.org/10.1016/j.pragma.2018.05.001

McMahon, J., McGannon, K. R., \& Zehntner, C. (2017). Slim to win: An ethnodrama of three elite swimmers' "presentation of self" in relation to a dominant cultural ideology. Sociology of Sport Journal, 34(2), 108-123. https://doi.org/10.1123/ssj.2015-0166

Mueller, F. (2018). Taking Goffman seriously: Developing strategy-as-practice. Critical Perspectives on Accounting, 53, 16-30. https://doi.org/10.1016/j.cpa.2017.03.009

Pires, R. P. (2012). O problema da ordem [The issue of order]. Sociologia, Problemas e Práticas, 69, 31-45. https://doi.org/10.7458/spp201269785

Plummer, K. (2000). Symbolic interactionism in the twentieth century. In B. S. Turner (Ed.), The Blackwell companion to social theory $\left(2^{\text {nd }}\right.$ ed.) (pp. 193-222). Massachusstts and Oxford: Blackwell Publishers.

Portillo, S., Rudes, D. S., Viglione, J., \& Nelson, M. (2013). Front-stage stars and backstage producers: The role of judges in problem-solving courts. Victims \& Offenders, 8(1), 1-22. https://doi.org/10.1080/15564886.2012.685220

Qi, J., Monod, E., Fang, B., \& Deng, S. (2018). Theories of social media: Philosophical foundations. Engineering, 4(1), 94-102. https://doi.org/10.1016/j.eng.2018.02.009

Richey, M., Gonibeed, A., \& Ravishankar, M. N. (2018). The perils and promises of self-disclosure on social media. Information Systems Frontiers, 20(3), 425-437. https://doi.org/10.1007/s10796-017-9806-7

Salvini, L., Souza, J. de, \& Marchi Júnior, W. (2015). Entre fachadas, bastidores e estigmas: Uma análise sociológica do futebol feminino a partir da teoria da ação social de Erving Goffman [Between frontage, backstage and stigmata: A sociological analysis of women's football based on Erving Goffman's social action theory]. Revista Brasileira de Educação Física e Esporte, 29(4), 559-569. https://doi.org/10.1590/1807-55092015000400559

Serpa, S. (2014). O contributo do conceito de instituição total para uma leitura empírica de um contexto educativo [The contribution of the concept of total institution to an empirical reading of an educational context]. Atas do VIII Congresso Português de Sociologia [Proceedings of the VIII Portuguese Congress of Sociology]. Lisbon: Portuguese Sociology Association. Available at http://www.aps.pt/viii_congresso/VIII_ACTAS/VIII_COM0101.pdf.

Thornborrow, J., \& Haarman, L. (2012). Backstage activities as frontstage news. European Journal of Communication, 27(4), 376-394. https://doi.org/10.1177/0267323112459529

Vigmo, S., \& Lantz-Andersson, A. (2014). Language in the wild - Living the carnival in social media. Social Sciences, 3(4), 871-892. https://doi.org/10.3390/socsci3040871

Walsh, M. J., \& Baker, S. A. (2017). The selfie and the transformation of the public-private distinction. Information, Communication \& Society, 20(8), 1185-1203. https://doi.org/10.1080/1369118x.2016.1220969

Werner, A., \& Malterud, K. (2016). Children of parents with alcohol problems performing normality: A qualitative interview study about unmet needs for professional support. International Journal of Qualitative Studies on Health and Well-Being, 11(1). https://doi.org/10.3402/qhw.v11.30673

Wilkinson, C. (2017). Going "backstage": Observant participation in research with young people. Children's Geographies, 15(5), 614-620. https://doi.org/10.1080/14733285.2017.1290924

\section{Copyrights}

Copyright for this article is retained by the author(s), with first publication rights granted to the journal.

This is an open-access article distributed under the terms and conditions of the Creative Commons Attribution license which permits unrestricted use, distribution, and reproduction in any medium, provided the original work is properly cited. 